\title{
Knowledge, attitude and practice towards the implementation of outcome-based education among the academics in Universiti Putra Malaysia
}

\author{
Siti Fatimah Mohamad, Ungku Fatimah Ungku Zainal Abidin, Nazamid Saari,Muta Harah \\ Zakaria, Alyani Ismail, Nor Azirawani Man
}

\begin{abstract}
Numerous efforts have been taken to prepare graduates for employment right after their graduations. The statistics show that over 53,000 of Malaysian graduates were unemployed in 2017 and expected to increase in 2018 as the total unemployment for all group of people in July 2018 was 518,600. Although the outcome-based education (OBE) has been advocated in the 1970s to improve students' achievement, higher education institutions are still struggling to produce quality and capable graduates to the industry. As the new education systems are emerging from time to time, academics of higher education institutions might have different interpretations of outcome-based education and its practices. Therefore, this study was conducted to identify the level of knowledge, attitude, and practice (KAP) relating to the OBE among academics in Universiti Putra Malaysia and to compare the respondents' work profile characteristics with the KAP towards the implementation of the OBE. A total of 173 academics participated in this study through an online survey. The findings of this study indicated that the majority of the respondents were well versed with the knowledge of $O B E$ and have a positive attitude and practices towards the implementation of OBE. Next, the results show that there are significant differences between positions on the respondents' knowledge, and for the year of service in UPM on respondents' attitude and practices towards the $O B E$ implementation. It is anticipated that the findings from this study may help the university to improve the $O B E$ system and to prepare the academics with the right knowledge, attitude, and practice towards the OBE implementation.
\end{abstract}

Keywords: Attitude, Knowledge, Outcome-based education, Practice

\section{INTRODUCTION}

The primary purpose of an educational system is to convey knowledge to the learning community to prepare graduates for life in the industry and society [1]. The traditional learning methodologies assume that schools are likely to produce employable students if the schools are able

Revised Manuscript Received on April 19, 2019.

Siti Fatimah Mohamad, Faculty of Food Science and Technology, Universiti Putra Malaysia, 43400 Serdang, Selangor, Malaysia.

Ungku Fatimah Ungku Zainal Abidin, Faculty of Food Science and Technology, Universiti Putra Malaysia, 43400 Serdang, Selangor, Malaysia.

Nazamid Saari, Faculty of Food Science and Technology, Universiti Putra Malaysia, 43400 Serdang, Selangor, Malaysia.

Muta Harah Zakaria, Faculty of Agriculture, Universiti Putra Malaysia, 43400 Serdang, Selangor, Malaysia.

Alyani Ismail, Faculty of Engineering, Universiti Putra Malaysia, 43400 Serdang, Selangor, Malaysia.

Nor Azirawani Man, Centre for Academic Development, Universiti Putra Malaysia, 43400 Serdang, Selangor, Malaysia. in providing better inputs - committed teachers, conducive learning rooms, state-of-the-art facilities, latest curriculum, and excellent learning experiences [2]. However, many believe that these methodologies have failed to prepare graduates for life outside of school adequately. For example, in 2017 , there were over 53,000 of unemployed graduates reported in Graduate Tracer Study [3]. To date, the report on unemployed graduates for 2018 is yet to be available, but the number of unemployed graduates is expected to increase as the total of unemployment for all group of people in July 2018 was 518,600 [4]. The unemployment factors include lack of job experience and positive attitudes, poor English language command, inadequate communication and interpersonal skills, and also irrelevant qualifications [5-9]. In consequence, the outcome-based education (OBE) has been introduced and implemented at all levels of education, especially at the level of tertiary education in Malaysia as part of education reform. This is due to the demand for quality and capable graduates to fulfill industrial needs [10 12]. However, the implementation of OBE in the Malaysian education system is still relatively new [13]. As in many cases, when educational reform was introduced, the impact was usually diverse and characterized by resistance, ignorance, instrumental change or adaptation [14-16]. Harden [14] emphasized that the delivery of OBE was considered failed due to the lack of support from the lecturers with poor knowledge and lack of involvement. Hence, lecturers' understanding of OBE is important [17]. However, different lecturers have a different understanding of the relation between aims, learning outcomes and instructional design [16]. Similarly, lecturers will have different interpretation towards OBE implementation and its practice [18]. However, many previous studies focused only on the lecturer's roles in implementing the assessment including the assessment process, case studies of the successfully implemented assessment programs, and strategies to administer assessment [14, 19-23]. In addition, there is also a lack of studies on the OBE implementation as an approach in practice and only a few studies were conducted qualitatively to explore the extent of OBE understanding among educators [18, 24]. Thus, this study aims to identify the level of KAP relating to the OBE among academics in UPM and to compare the respondents' work

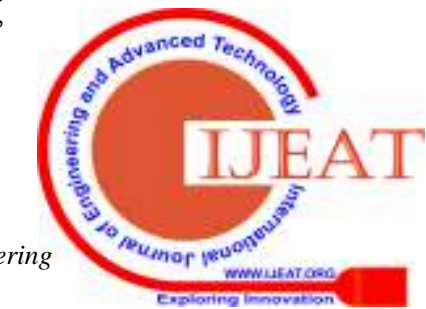


profile characteristics with the KAP.

\section{LITERATURE REVIEW}

\section{a. Definitions of $O B E$}

The OBE has been advocated since the early 1970s with Mager's instructional objectives [25]. Previously, OBE is defined as teaching and learning targeting outcomes of knowledge, competence and orientation for the affective and attitudinal dimensions of learning [26]. OBE is also considered as the comprehensive approach that is focused on organizing and operating everything in an educational system on what is essential for all students to be able to do successfully at the end of their learning experiences, such as organizing the curriculum, instruction, and assessment [27]. Spady [27] also mentioned OBE as an educational process to develop the design of structures and curricula, including the required students' capabilities and qualities to achieve specified outcomes. Similarly, Shields [28] has the same thought as Spady [27]. It is concluded that the principal basis of $\mathrm{OBE}$ is determining and producing appropriate outcomes rather than inputs [13].

\section{b. $\quad$ The Characteristics of $O B E$}

The previous educational system which is the traditional approach has failed to adequately prepare the student for life and work [2]. The proposed system, which is OBE, has been introduced and implemented to rectify it. Spady [27] has differentiated the traditional education approach and the OBE approach in four key areas. Firstly, the framework of the end outcomes for OBE is defined clearly in which the curriculum, instruction, and assessment are flexible and can be altered in accomplishing the defined learning outcome, while the framework for traditional education is not flexible as it has fix curriculum structure with undefined outcomes expected for all students. Secondly, time can be manipulated for $\mathrm{OBE}$ as an alterable resource within reasonable constraints, depending on the teachers' and students' needs, while for traditional education, the student learning and success are being controlled with schedule and calendar. Next, the OBE system allows all students to receive full credit for achieving any performance standard without predetermining specified quotas for who can be successful or what standards can be pursued. However, the traditional education system operates in contrast, which uses a comparative or competitive approach that only some students can be a success and do well while others are not. Lastly, Spady [27] mentioned that the OBE system is differentiated from the traditional education system in which OBE focuses to improve the learning and performance abilities of the students before graduated or leaving the school.

On the other hand, traditional education system only emphasizes and rewards students with excellent performance, in which the fast and consistent students get the best grades and records, while slower students do not get the opportunity to catch up due to their records. According to Du Plessis [1], the learners from OBE are more active as they are being assessed on an ongoing basis that encouraged critical thinking, reasoning, reflection, and action. Next, the learning process for $\mathrm{OBE}$ is learner-centered and the learners take responsibility for their learning and are motivated by feedback and affirmation of their worth [1,
13]. Thus, it is claimed that OBE is the key for student employability [2].

c. The implementation of OBE in higher education institutions

Nowadays, higher education institutions were shifting their learning methodologies by focusing more on outcomes rather than inputs to prepare graduates with the required knowledge and skills [2]. This is due to the reports on the growing number of unemployed graduates that is lack of job experience and positive attitude, poor English language command, inadequate communication and interpersonal skills and irrelevant qualifications [5-9]. OBE has been introduced and implemented at all levels of education including the higher education institutions in Malaysia as part of education reform due to the demand for quality and capable graduates to fulfill industrial needs [10-12].

The higher education system in Malaysia is focusing on students' outcomes over inputs to address students' needs and enable greater personalization of the learning experience [29]. In order to achieve specified learning outcomes, it is essential to have appropriate assessment methods [30]. Boud and Falchikov [31] reported that assessments in higher education institutions were insufficient to prepare the students for long-term learning experiences. Formative and summative assessments have been received a considerable critique on the effect of learning within courses [31]. Thus, higher education institutions should reanalyse the purpose of assessments in order to prepare students with the reality of life after graduation [32]. This lead to new assessment practices that have been designed to address a wider range of learning outcomes [31]. As for the higher education institutions in Malaysia, there are five clusters of learning outcomes: i) knowledge and understanding, ii) cognitive skills, iii) functional work skills with focus on practical skills, interpersonal skills, communication skills, digital skills, numeracy skills, leadership, autonomy and responsibility, iv) personal and entrepreneurial skills, and finally v) ethics and professionalism (33). All programmes and qualifications in Malaysia higher education institutions should comply with the latest edition of MQF to obtain accreditation, besides ensuring the effectiveness and consistency of the achievements in the learning process.

\section{METHODOLOGY}

The development of the questions was based on the literature review [7, 22, 26, 27], referring to the UPM teaching and learning modules, and also discussion with the experts, to suit the context of teaching and learning in UPM. The survey questions related to the objective of this paper are: i) KAP related to the OBE, and ii) respondent's demographic and work profile. There are 30 questions for the KAP related to the OBE, with ten questions for each respective KAP. Respondents had three options for the answer on the knowledge part relating to the OBE: "True", "False", and "Do not know". On the other hand, the items on the attitude and practice relating to OBE applied 5-point Likert scale: "1-strongly disagree", "2-disagree", "3- 
neutral", "4-agree", and "5-strongly agree". Thedemographic and work profile sections, the questions included the name of the faculty and department, position, age, gender, year of services, teaching credit and number of courses being taught by the academicians in UPM in the semester I (2018/2019). The question of attending seminars related to OBE was also included in the work profile section.

The data collection was initially started by getting the total number of academics and their emails from the UPM Registrar. The invitation email for the online survey was sent directly to each academic. Reminders were sent form time to time to increase the participation rate. Also, email and WhatsApp were sent to all deans and deputy dean of academics of each faculty to promote the online survey of the study, followed with phone calls as the reminder. Participants were offered incentives by participating in this study and the value of the incentives was raised towards the deadline of the survey. Though various efforts had been taken to maximize the response rate, this study only able to obtain $11 \%$ of response rate. This rate can be considered as acceptable by previous researchers $[33,34]$.

The overall project of this study comprising both quantitative and qualitative data. This paper is merely reporting part of the study, which is the quantitative data. An online survey was employed as the quantitative approach, where the survey link was emailed to all 1614 academics in UPM, where the positions for the academics range from professors, associate professors, senior lecturers and lecturers. The sample size of the convenience sampling that was collected is 173 responses, where the survey was based on the voluntarily and it was not compulsory for the academics to participate. The response rate of the online survey has been discussed to be lower compared to the paper-based survey, due to several factors that lead to the disadvantages of employing the online survey [35-38]. However, the online survey was implemented due to budget constraint and time limitation.

The quantitative data were analyzed using the IBM SPSS Version 23. The analysis comprises descriptive analysis and ANOVA test. The next section discusses the results for the level of KAP and the analysis of the work profiles difference on the respondents' KAP towards the implementation of OBE.

\section{RESULTS AND DISCUSSION}

\section{a. Demographic and Work Profile of the Respondents}

One hundred and seventy-three academics from Universiti Putra Malaysia responded to the survey. The female respondents comprised $70.5 \%$ (122) of the sample, followed by male respondents $29.5 \%$ (51). Most of the respondents were between 30 to 49 years old. For the respondents' work profiles, the data were analyzed based on the faculty, positions, attendance of OBE seminars, and year of services. The respondents were from 15 faculties and most of them were from the Faculty of Engineering (24,
13.9\%) and Faculty of Medicine and Health Science (24, $13.9 \%$ ). Majority of the respondents were senior lecturers, and only eight respondents $(4.6 \%)$ were professors. Among the respondents, $114(65.9 \%)$ have attended the seminar related to OBE implementation in 2018. Twelve (6.9\%) respondents have more than 20 years working experience in UPM, while $23(13.3 \%)$ respondents have one year and less of working experience in UPM. About 47 respondents $(27.2 \%)$ have two to five years of working experience in UPM. Majority of the respondents $(147,85 \%)$ reported that they had not taught courses that are outside of their area of expertise.

\section{b. The Level of Respondents' Knowledge Towards the Implementation of $O B E$}

The knowledge assessment consists of 10 questions with three choices of answers (do not know; false; and true). The correct answer for questions one to four and seven to eight are "true", while the correct answer for questions five to six, and nine to ten are "false". Each question in the knowledge assessment is labeled as $\mathrm{K} 1$ to $\mathrm{K} 10$, as shown in Table I. Most of the respondents $(n=162,93.6 \%)$ correctly answered $\mathrm{K} 1$, while 156 respondents $(90.2 \%)$ correctly had the correct answer for K2. However, when compared between the "false" and "don't know" answer for K2, more respondents picked "do not know" which indicated that there are unfamiliar with the OBE process that consists of four interconnected stages. K3 indicated that 145 respondents $(83.8 \%)$ know the correct answers and 157 respondents $(90.8 \%)$ also correctly identified "true" as the correct answer for K4. On the other hand, majority of the respondents did not have knowledge for K5 $(n=123,71.1)$ and $K 6(n=94$, 54.3). Most of the respondents were able to identify the correct answer for $\mathrm{K} 7$ and $\mathrm{K} 8$, with $\mathrm{n}=131$ (75.7\%) and $\mathrm{n}=134(77.5 \% \%)$, respectively. The results for the last two questions, $\mathrm{K} 9$ and $\mathrm{K} 10$, indicated that majority of the respondents did not have knowledge pertaining to the questions $\quad(n=98, \quad 56.6 \%$ and $n=119, \quad 68.8 \%)$. It can be concluded that most of the respondents did not have knowledge on four questions, which related to the time of Program Educational Objectives (PEO) and Program Outcomes (PO) assessments (K5 and K9), stages in the cognitive domain (K6), and the specific PO under the cognitive domain (K10). On the other hand, six questions were answered correctly by the majority of the respondents. The highest percentage of correct responses (93.6\%) belongs to K1 with the statement "In the OBE learning, the faculty should be first determined what skills and knowledge students should possess upon graduation, and then work backward from there to develop curriculum". It is followed with $\mathrm{K} 4$ as the second highest percentage of correct responses $(90.8 \%)$ which is "One of the key questions addressed by the OBE is "how will you know what they have learnt?". The results indicated that the majority of respondents were well informed of the basic questions in the OBEimplementation. 
International Conference on Recents Advancements in Engineering and Technology (ICRAET-18) |15th and 16th March 2019|Siddhartha Institute of Technology \& Sciences, Telangana, India.

Table I: Respondent' Knowledge Scores On OBE

\begin{tabular}{|c|c|c|c|}
\hline \multirow[t]{2}{*}{ No } & \multirow[t]{2}{*}{ Statements } & \multicolumn{2}{|c|}{ Respondent \% (n) } \\
\hline & & No Knowledge & Has knowledge \\
\hline $\mathrm{K} 1$ & $\begin{array}{l}\text { In the OBE learning, the faculty should be first } \\
\text { determined what skills and knowledge students } \\
\text { should possess upon graduation, and then work } \\
\text { backward from there to develop curriculum. }\end{array}$ & $6.4(11)$ & $93.6(162)$ \\
\hline $\mathrm{K} 2$ & $\begin{array}{l}\text { The OBE process comprises four interconnected } \\
\text { stages; planning/review, developing, } \\
\text { implementing, and evaluating. }\end{array}$ & $9.8(17)$ & $90.2(156)$ \\
\hline K3 & $\begin{array}{l}\text { There is a difference between the Program } \\
\text { Educational Objectives (PEO) and Program } \\
\text { Outcomes (PO) }\end{array}$ & $16.2(28)$ & $83.8(145)$ \\
\hline $\mathrm{K} 4$ & $\begin{array}{l}\text { One of the key questions addressed by the OBE is } \\
\text { "how will you know what they have learnt?" }\end{array}$ & $9.2(16)$ & $90.8(157)$ \\
\hline K5 & $\begin{array}{l}\text { The Program Educational Objectives (PEO) are } \\
\text { assessed upon graduation. }\end{array}$ & $71.1(123)$ & $28.9(50)$ \\
\hline K6 & There are five stages in the cognitive domain. & $54.3(94)$ & $45.7(79)$ \\
\hline K7 & $\begin{array}{l}\text { There are nine program outcomes (PO) outlined } \\
\text { by UPM, where there is only one PO (PO2) } \\
\text { belongs to the psychomotor domain. }\end{array}$ & $24.3(42)$ & $75.7(131)$ \\
\hline K8 & $\begin{array}{l}\text { There are seven soft skill elements and there is a } \\
\text { minimum level to be reached (Kemahiran Insaniah } \\
\text { Mesti) for each element. }\end{array}$ & $22.5(39)$ & $77.5(134)$ \\
\hline K9 & $\begin{array}{l}\text { The Programme Outcomes (PO) are assessed three } \\
\text { to five years after graduation. }\end{array}$ & $56.6(98)$ & $43.4(75)$ \\
\hline K10 & $\begin{array}{l}\text { PO1 (Knowledge), PO3 (Critical thinking and } \\
\text { problem solving) and PO7 (Information } \\
\text { management and lifelong learning skills) are the } \\
\text { program outcomes (PO) under the cognitive } \\
\text { domain. }\end{array}$ & $68.8(119)$ & $31.2(54)$ \\
\hline
\end{tabular}

c. The Level Of Respondents' Attitude Towards The Implementation Of Obe

The attitudes of the respondents towards the implementation of OBE are shown in Table II. Each question in the attitude statement is labeled as A1 to A10. The respondents' level of attitude towards the implementation of OBE was measured using a 5-point Likert scale ( 1 = Strongly disagree; $5=$ Strongly agree). The highest mean score was observed in statement $\mathrm{A} 1$, which is 4.14 ( $\mathrm{SD}=0.805)$, where most respondents indicated that they have a vision on how the graduates should be in the future. The second highest mean score was recorded in statement A2 which is 4.07 ( $\mathrm{SD}=0.846)$, where the respondents agreed that they were clear about the program outcomes and believed that it reflects the criteria that should be possessed by the graduates. The third highest mean score is 4.06 ( $\mathrm{SD}=0.941)$, in A4 statement, where $83.2 \%$ of the respondents agreed that the objectives of program education could be achieved through the synchronization among the program courses' learning outcomes. On the other hand, the lowest mean score is 2.60 ( $\mathrm{SD}=1.124)$, represented by the A6 statement. Some respondents $(21.9 \%)$ were unsatisfied with the eSMP system and other system related to OBE program, where they agreed that the eSMP system and other systems related to OBE was frustrating. The overall results for the level of attitude indicate that majority of the respondents have a positive attitude towards the implementation of OBE program; only several respondents have a negative attitude towards the OBE-related systems (i.e., eSMP).

\section{d. The Level of Respondents' Practice Relating to the} Implementation of $O B E$

Table iii presents the mean score result for ten statements on respondents' practices related to obe, which is labeled as p1 to p10. The result shows that the highest mean score 4.28 ( $\mathrm{sd}=0.795)$ was recorded for the statement of $\mathrm{p} 4$ (" $\mathrm{i}$ provide a course outline to my students to help them foresee the knowledge and skills to be acquired from the course"). The second highest mean score was $4.05(\mathrm{sd}=0.746)$ as observed in statement $\mathrm{p} 7$; where $86.7 \%(\mathrm{n}=150)$ respondents indicated that they conducted assessments based on the course learning outcome to evaluate their students' achievement. The third highest mean score is $4.00(\mathrm{sd}=0.863)$, where $81.5 \%(n=141)$ respondents agreed with the following statement "i review the teaching plan yearly and improve accordingly".

Meanwhile, the lowest mean score is $3.23(\mathrm{sd}=0.996)$, where only $43.4 \%(n=75)$ of the respondents stated that they developed weekly learning outcomes that can be measured through the esmp system (statement $\mathrm{p} 1$ ). The second lowest mean score is $3.25(\mathrm{sd}=1.024)$, where the statement also related to the esmp system (statement p3). Only $47.4 \%$ $(n=82)$ of the respondents agreed that the essmp system is 
helpful in the process of planning and implementing the teaching and learning activities

Table II: Respondents' Attitude Towards the Implementation of OBE

\begin{tabular}{|c|c|c|c|c|c|c|c|c|}
\hline No. & Statement & & $\operatorname{Re}$ & ndent & (n) & & Mean & SD \\
\hline & & $\mathbf{1}$ & 2 & 3 & 4 & 5 & & \\
\hline A1 & I have a vision of how our graduates should become. & $\begin{array}{l}2.3 \\
(4)\end{array}$ & $\begin{array}{l}1.7 \\
\text { (3) }\end{array}$ & $\begin{array}{l}6.9 \\
(12)\end{array}$ & $\begin{array}{l}57.2 \\
\text { (99) }\end{array}$ & $\begin{array}{l}31.8 \\
(55)\end{array}$ & 4.14 & 0.805 \\
\hline A2 & $\begin{array}{l}\text { I am clear about the program outcome and it reflects the criteria } \\
\text { that should be possessed by our graduates. }\end{array}$ & $\begin{array}{l}2.3 \\
\text { (4) }\end{array}$ & $\begin{array}{l}1.7 \\
\text { (3) }\end{array}$ & $\begin{array}{l}13.3 \\
(23)\end{array}$ & $\begin{array}{l}52.0 \\
(90)\end{array}$ & $\begin{array}{r}30.6 \\
(53)\end{array}$ & 4.07 & 0.846 \\
\hline A3 & $\begin{array}{l}\text { The seminar/ workshop organized by CADe help us to better } \\
\text { understand the implementation and significance of OBE. }\end{array}$ & $\begin{array}{l}4.0 \\
(7)\end{array}$ & $\begin{array}{l}3.5 \\
(6)\end{array}$ & $\begin{array}{l}18.5 \\
(32)\end{array}$ & $\begin{array}{l}46.2 \\
(80)\end{array}$ & $\begin{array}{l}27.7 \\
(48)\end{array}$ & 3.90 & 0.980 \\
\hline A4 & $\begin{array}{l}\text { I believe by having a synchronization among the program } \\
\text { courses' learning outcomes, the program education objectives } \\
\text { can be achieved. }\end{array}$ & $\begin{array}{l}3.5 \\
(6)\end{array}$ & $\begin{array}{l}3.5 \\
(6)\end{array}$ & $\begin{array}{l}9.8 \\
(17)\end{array}$ & $\begin{array}{l}49.7 \\
(86)\end{array}$ & $\begin{array}{l}33.5 \\
(58)\end{array}$ & 4.06 & 0.941 \\
\hline A5 & $\begin{array}{l}\text { The success of the OBE implementation derived from the effort } \\
\text { put in the teaching plan documentation. }\end{array}$ & $\begin{array}{l}6.4 \\
(11)\end{array}$ & $\begin{array}{l}6.4 \\
(11)\end{array}$ & $\begin{array}{l}15.0 \\
(26)\end{array}$ & $\begin{array}{l}47.4 \\
(82)\end{array}$ & $\begin{array}{l}24.9 \\
(43)\end{array}$ & 3.78 & 1.088 \\
\hline A6 & $\begin{array}{l}\text { Using the eSMP system and other systems in UPM that are } \\
\text { related to OBE is frustrating.* }\end{array}$ & $\begin{array}{l}19.7 \\
(34)\end{array}$ & $\begin{array}{l}27.2 \\
(47)\end{array}$ & $\begin{array}{l}31.2 \\
(54)\end{array}$ & $\begin{array}{l}17.3 \\
(30)\end{array}$ & $\begin{array}{l}4.6 \\
(8)\end{array}$ & 2.60 & 1.124 \\
\hline A7 & $\begin{array}{l}\text { I believe by giving the information of course outcomes, a list of } \\
\text { weekly topic and type of assessment to students, they can foresee } \\
\text { the knowledge and skills to be acquired from the course. }\end{array}$ & 5.8 & $\begin{array}{l}5.8 \\
(10)\end{array}$ & $\begin{array}{l}11.0 \\
(19)\end{array}$ & $\begin{array}{l}52.0 \\
(90)\end{array}$ & $\begin{array}{l}25.4 \\
\text { (44) }\end{array}$ & 3.86 & 1.049 \\
\hline A8 & $\begin{array}{l}\text { I believe formative assessment is intended to give opportunities } \\
\text { to students to improve their skills and knowledge. }\end{array}$ & $\begin{array}{l}4.6 \\
(8)\end{array}$ & $\begin{array}{l}2.3 \\
(4)\end{array}$ & $\begin{array}{l}7.5 \\
(13)\end{array}$ & $\begin{array}{l}53.2 \\
(92)\end{array}$ & $\begin{array}{l}32.4 \\
(56)\end{array}$ & 4.06 & 0.953 \\
\hline A9 & Documenting an assessment rubric is just a waste of time.* & $\begin{array}{l}9.8 \\
(17)\end{array}$ & $\begin{array}{l}9.8 \\
(17)\end{array}$ & $\begin{array}{l}28.9 \\
(50)\end{array}$ & $\begin{array}{l}30.6 \\
(53)\end{array}$ & $\begin{array}{l}20.8 \\
(36)\end{array}$ & 3.43 & 1.206 \\
\hline A10 & $\begin{array}{l}\text { I believe the implementation of OBE helps the students to } \\
\text { acquire intended knowledge and skills. }\end{array}$ & $\begin{array}{l}5.2 \\
\text { (9) }\end{array}$ & $\begin{array}{l}4.0 \\
(7)\end{array}$ & $\begin{array}{l}16.2 \\
(28)\end{array}$ & $\begin{array}{l}48.6 \\
(84)\end{array}$ & $\begin{array}{l}26.0 \\
(45)\end{array}$ & 3.86 & 1.019 \\
\hline
\end{tabular}

Note: Scale used: 1- Strongly disagree, 2- Disagree, 3- Neutral, 4- Agree, 5- Strongly agree (*Reverse code items)

Scale Reliability (Cronbach-alpha) $=0.869$

Table III: Respondents' Practice Relating to the Implementation of OBE

\begin{tabular}{|c|l|c|c|c|c|c|c|c|}
\hline No. & \multicolumn{2}{|c|}{ Statement } & \multicolumn{3}{c|}{ Respondent \% (n) } & Mean & SD \\
\hline & & $\mathbf{2}$ & $\mathbf{2}$ & $\mathbf{3}$ & $\mathbf{4}$ & $\mathbf{5}$ & \\
\hline P1 & $\begin{array}{l}\text { I develop weekly learning outcomes that are } \\
\text { measurable in the eSMP system. }\end{array}$ & 4.0 & 20.2 & 32.4 & 35.3 & 8.1 & 3.23 & 0.996 \\
(7) & (35) & (56) & (61) & (14) & \\
\hline
\end{tabular}


International Conference on Recents Advancements in Engineering and Technology (ICRAET-18) |15th and 16th March 2019|Siddhartha Institute of Technology \& Sciences, Telangana, India.

\begin{tabular}{|c|c|c|c|c|c|c|c|c|}
\hline $\mathrm{P} 2$ & $\begin{array}{l}\text { I review the teaching plan yearly and improve } \\
\text { accordingly. }\end{array}$ & 2.3 & $\begin{array}{l}3.5 \\
(6)\end{array}$ & $\begin{array}{l}12.7 \\
(22)\end{array}$ & $\begin{array}{l}54.9 \\
(95)\end{array}$ & $\begin{array}{l}26.6 \\
(46)\end{array}$ & 4.00 & 0.863 \\
\hline P3 & $\begin{array}{l}\text { The eSMP system facilitates my tasks in planning } \\
\text { and implementing the teaching and learning } \\
\text { activities. }\end{array}$ & $\begin{array}{l}4.0 \\
(7)\end{array}$ & $\begin{array}{l}22.5 \\
(39)\end{array}$ & $\begin{array}{l}26.0 \\
(45)\end{array}$ & $\begin{array}{l}39.3 \\
(68)\end{array}$ & $\begin{array}{l}8.1 \\
(14)\end{array}$ & 3.25 & 1.024 \\
\hline $\mathrm{P} 4$ & $\begin{array}{l}\text { I provide a course outline to my students to help } \\
\text { them foresee the knowledge and skills to be } \\
\text { acquired from the course. }\end{array}$ & $\begin{array}{l}2.3 \\
(4)\end{array}$ & $\begin{array}{l}0.6 \\
(1)\end{array}$ & $\begin{array}{l}5.8 \\
(10)\end{array}$ & $\begin{array}{l}49.7 \\
(86)\end{array}$ & $\begin{array}{l}41.6 \\
(72)\end{array}$ & 4.28 & 0.795 \\
\hline P5 & $\begin{array}{l}\text { I have included the learning outcome for each topic } \\
\text { in the slides/notes of my class. }\end{array}$ & $\begin{array}{l}4.0 \\
(7)\end{array}$ & $\begin{array}{l}8.1 \\
(14)\end{array}$ & $\begin{array}{l}17.3 \\
(30)\end{array}$ & $\begin{array}{l}45.1 \\
(78)\end{array}$ & $\begin{array}{l}25.4 \\
(44)\end{array}$ & 3.80 & 1.040 \\
\hline P6 & $\begin{array}{l}\text { My course learning outcomes have been achieved } \\
\text { through the assessments. }\end{array}$ & $\begin{array}{l}2.3 \\
(4)\end{array}$ & $\begin{array}{l}1.7 \\
(3)\end{array}$ & $\begin{array}{l}15.6 \\
(27)\end{array}$ & $\begin{array}{l}63.6 \\
(110)\end{array}$ & $\begin{array}{l}16.8 \\
(29)\end{array}$ & 3.91 & 0.772 \\
\hline $\mathrm{P} 7$ & $\begin{array}{l}\text { I assess students based on the course learning } \\
\text { outcomes which the students are required to } \\
\text { demonstrate/ achieved. }\end{array}$ & $\begin{array}{l}1.7 \\
(3)\end{array}$ & $\begin{array}{l}1.7 \\
(3)\end{array}$ & $\begin{array}{l}9.8 \\
(17)\end{array}$ & $\begin{array}{l}63.6 \\
(110)\end{array}$ & $\begin{array}{l}23.1 \\
(40)\end{array}$ & 4.05 & 0.746 \\
\hline P8 & I use rubrics for the student's assessment. & $\begin{array}{l}4.0 \\
(7)\end{array}$ & $\begin{array}{l}4.6 \\
(8)\end{array}$ & $\begin{array}{l}19.7 \\
(34)\end{array}$ & $\begin{array}{l}52.6 \\
(91)\end{array}$ & $\begin{array}{l}19.1 \\
(33)\end{array}$ & 3.78 & 0.945 \\
\hline P9 & $\begin{array}{l}\text { I take formative approach to provide students } \\
\text { multiple opportunities to master important } \\
\text { objectives in my course. }\end{array}$ & $\begin{array}{l}1.7 \\
(3)\end{array}$ & $\begin{array}{l}1.2 \\
(2)\end{array}$ & $\begin{array}{l}13.9 \\
(24)\end{array}$ & $\begin{array}{l}64.2 \\
(111)\end{array}$ & $\begin{array}{l}19.1 \\
(33)\end{array}$ & 3.98 & 0.731 \\
\hline $\mathrm{P} 10$ & $\begin{array}{l}\text { I provide feedback (e.g.: corrective instruction) to } \\
\text { all students in order to master important objectives } \\
\text { in my } \\
\text { course. }\end{array}$ & $\begin{array}{l}2.3 \\
(4)\end{array}$ & $\begin{array}{l}0.6 \\
(1)\end{array}$ & $\begin{array}{l}17.9 \\
(31)\end{array}$ & $\begin{array}{c}58.4 \\
101\end{array}$ & $\begin{array}{l}20.8 \\
(36)\end{array}$ & 3.95 & 0.787 \\
\hline
\end{tabular}

e. Comparison Between the Work Profile Characteristics and KAP Towards the Implementation of $O B E$

A one-way ANOVA was used to determine whether respondents' work profile characteristics have an impact on their KAP towards the OBE implementation. The independent variables are represented by four different work profile characteristics: faculty, position, attendance of the OBE seminar, and year of service in UPM. The dependent variable was the respondents' scores of KAP towards the implementation of OBE. The impact of work profile on respondents' KAP toward the implementation of OBE is presented in Table IV. It can be concluded that the only differences for the profiles on the respondents' KAP towards the OBE implementation are knowledge from different positions, attitude and practice from different years of service in UPM.

The ANOVA test indicates there is a significant difference in the practice of the faculty profile. However, when the Tukey post hoc test was conducted to see which faculties are different, there is no significant difference between the faculties. The results also show that there are no significant difference in mean knowledge score, mean attitude score and mean practice score for the profile of attending seminar related to OBE.

The impact of respondents' position on the KAP towards the implementation of $\mathrm{OBE}$ is also assessed. The result shows that there is a significant difference (at the level $\mathrm{p}<0.05)$ in knowledge scores for the four position groups, Brown-Forsythe test $(F(3,169)=0.02, p=0.028)$. The 
Tukey post hoc test conducted reveals that the mean knowledge score of respondents with lecturer's position $(12.84 \pm 4.622)$ is significantly different from the respondents with senior lecturer's position $(16.08 \pm 3.094)$ and associate professor's position $(16.16 \pm 2.296)$. The mean score knowledge of respondents with professor's position $(14.13 \pm 5.384)$ does not differ significantly from the other three groups of respondents' positions. On the other hand, the respondents' position does not have a significant impact on the respondents' attitude and practice towards the implementation of OBE.

For the impact of years of service in UPM on the respondents' knowledge related to the OBE implementation, the result shows that there is no significant difference at the level $\mathrm{p}<0.05$ in mean knowledge score due to the respondents' years of service in UPM. Meanwhile, there is a significant difference at the level $\mathrm{p}<0.05$ in the mean attitude score using the Brown-Forsythe test $(\mathrm{F}(5,166)=$ $3.960, \mathrm{p}=0.004)$. Further, post-hoc comparisons using Tukey HSD test discovered that the mean attitude score for respondents who served for 11 to 15 years $(33.48 \pm 9.725)$ is significantly different from the respondents who have served only for one year and less $(41.48 \pm 4.263)$. The mean attitude score for respondents served for 11 to 15 years also significantly different from the respondents who served between 2 to 5 years $(38.11 \pm 6.158)$, and for the respondents who served for 6 to 10 years $(38.39 \pm 4.918)$. However, those who served for 11 to 15 years did not differ significantly from both groups of respondents who served for $16-20$ years $(38.04 \pm 5.841)$ or more than 21 years $(37.75 \pm 7.653)$. The years of service also shows an impact on the respondents' practice related to the OBE implementation. Results exhibit that there is a significant different at the level $\mathrm{p}<0.05$ in the mean practice scores using Brown-Forsythe test $(\mathrm{F}(5,166)=2.899, \mathrm{p}=0.031)$. Similarly, the Tukey HSD test also shows that the mean practice score for group of one year and less $(40.48 \pm 5.550)$ is significantly different from group of 11 to 15 years of service $(35.07 \pm 9.786)$. Results reveal that the mean practice score for group of 2 to 5 years of service is significantly different from group of 11 to 15 years of service $(35.07 \pm 9.786)$

\section{CONCLUSION}

This study has shown that the academics in Universiti Putra Malaysia has knowledge towards the implementation of OBE especially related to the foundation of the OBE. Next, the level of attitudes among these academics towards the implementation of OBE was also positive except for the OBE-related systems such as the eSMP system. In term of the practice, the findings reveal that the UPM academics had a positive level of practices towards the OBE implementation, particularly in providing the course outline to students and conducting assessments based on the course learning outcomes.

Besides, the comparison between respondents' work profile with the KAP towards the OBE implementation indicates that there are only significant differences for: 1) knowledge of different academic's positions, 2) attitude of different years of service in UPM, and 3) practice of different years of service in UPM. There is no difference for the faculty and attendance of the OBE seminar on the respondents' KAP.

The findings from this study are anticipated to provide insight to UPM to improve the OBE system and to strategize the components of the OBE training in order to prepare the academics with the right KAP towards the OBE implementation. The understanding of the level of knowledge, attitude and also practice among academics are important to ensure UPM will be able to achieve the results of the OBE implementation. As this study is focusing on academics from UPM, future research could extend this research on academics from various universities in Malaysia to improve the implementation and success of OBE in higher education institutions.

Table IV: Comparison of Work Profile and Means KAP Scores

\begin{tabular}{|c|c|c|c|c|c|c|c|}
\hline Variables & & Knowled & & Attitude & & Practice & \\
\hline & $\mathbf{n}$ & Mean \pm SD & $\mathbf{P}$ & Mean \pm SD & $\mathbf{P}$ & Mean \pm SD & $\mathbf{P}$ \\
\hline Faculty & & & .120 & & .208 & & $.031 *$ \\
\hline Faculty of Agriculture & 13 & $15.62 \pm 2.256$ & & $34.62 \pm 6.358$ & & $36.92 \pm 4.252$ & \\
\hline Faculty of Forestry & 3 & $19.00 \pm 1.732$ & & $41.67 \pm 6.110$ & & $41.33 \pm 3.786$ & \\
\hline Faculty of Veterinary Medicines & 6 & $16.83 \pm 1.472$ & & $38.33 \pm 12.307$ & & $40.83 \pm 5.382$ & \\
\hline $\begin{array}{l}\text { Faculty of Economics and } \\
\text { Management }\end{array}$ & 9 & $13.89 \pm 2.571$ & & $34.22 \pm 7.242$ & & $33.00 \pm 8.803$ & \\
\hline Faculty of Engineering & 24 & $16.92 \pm 2.041$ & & $37.88 \pm 7.725$ & & $39.29 \pm 7.369$ & \\
\hline Faculty of Educational Studies & 8 & $14.25 \pm 1.982$ & & $33.00 \pm 9.871$ & & $35.38 \pm 6.696$ & \\
\hline
\end{tabular}


International Conference on Recents Advancements in Engineering and Technology (ICRAET-18) |15th and 16th March 2019|Siddhartha Institute of Technology \& Sciences, Telangana, India.

\begin{tabular}{|c|c|c|c|c|c|c|c|}
\hline Faculty of Science & 16 & $15.63 \pm 3.181$ & & $38.69 \pm 6.690$ & & $39.25 \pm 4.740$ & \\
\hline $\begin{array}{l}\text { Faculty of Food Science and } \\
\text { Technology }\end{array}$ & 20 & $16.80 \pm 2.505$ & & $39.55 \pm 5.365$ & & $38.55 \pm 3.000$ & \\
\hline Faculty of Human Ecology & 14 & $14.79 \pm 3.262$ & & $37.71 \pm 3.931$ & & $39.14 \pm 2.770$ & \\
\hline $\begin{array}{l}\text { Faculty of Modern Language and } \\
\text { Communication }\end{array}$ & 8 & $16.00 \pm 3.162$ & & $38.13 \pm 7.846$ & & $37.50 \pm 5.529$ & \\
\hline $\begin{array}{l}\text { Faculty of Design and } \\
\text { Architecture }\end{array}$ & 5 & $14.60 \pm 7.162$ & & $42.20 \pm 6.261$ & & $43.60 \pm 5.177$ & \\
\hline $\begin{array}{l}\text { Faculty of Medicine and Health } \\
\text { Science }\end{array}$ & 24 & $13.92 \pm 5.216$ & & $39.21 \pm 4.995$ & & $37.21 \pm 5.778$ & \\
\hline $\begin{array}{l}\text { Faculty of Computer Science and } \\
\text { Information Technology }\end{array}$ & 14 & $16.79 \pm 2.359$ & & $35.21 \pm 6.762$ & & $35.79 \pm 7.678$ & \\
\hline $\begin{array}{l}\text { Faculty of Biotechnology and } \\
\text { Biomolecular Sciences }\end{array}$ & 6 & $15.33 \pm 3.445$ & & $40.00 \pm 5.404$ & & $43.33 \pm 5.428$ & \\
\hline Faculty of Environmental Studies & 3 & $15.67 \pm 3.215$ & & $40.00 \pm 6.557$ & & $40.00 \pm 7.000$ & \\
\hline Total & 173 & & & & & & \\
\hline Position & & & $.028^{* *}$ & & .618 & & .270 \\
\hline Lecturer & 19 & $12.84 \pm 4.622$ & & $37.11 \pm 7.233$ & & $38.05 \pm 5.441$ & \\
\hline Senior lecturer & 101 & $16.08 \pm 3.094$ & & $38.33 \pm 6.675$ & & $38.92 \pm 6.053$ & \\
\hline Associate professor & 45 & $16.16 \pm 2.296$ & & $36.78 \pm 7.465$ & & $36.84 \pm 6.186$ & \\
\hline Professor & 8 & $14.13 \pm 5.384$ & & $37.88 \pm 3.758$ & & $37.38 \pm 4.534$ & \\
\hline Total & 173 & & & & & & \\
\hline $\begin{array}{l}\text { Attend seminar related to OBE } \\
\text { in } 2018\end{array}$ & & & .077 & & .382 & & .094 \\
\hline 1 & 114 & $16.02 \pm 2.918$ & & $38.10 \pm 6.863$ & & $38.76 \pm 6.522$ & \\
\hline 2 & 59 & $14.95 \pm 4.087$ & & $37.14 \pm 6.791$ & & $37.15 \pm 4.657$ & \\
\hline Total & 173 & & & & & & \\
\hline Year of service in UPM & & & .128 & & $.004 * *$ & & $.031 * *$ \\
\hline 1 year and less & 23 & $15.83 \pm 3.420$ & & $41.48 \pm 4.263$ & & $40.48 \pm 5.550$ & \\
\hline $2-5$ years & 47 & $16.17 \pm 2.640$ & & $38.11 \pm 6.158$ & & $39.28 \pm 3.938$ & \\
\hline $6-10$ years & 36 & $14.44 \pm 4.861$ & & $38.39 \pm 4.918$ & & $38.67 \pm 4.598$ & \\
\hline $11-15$ years & 27 & $16.33 \pm 2.287$ & & $33.48 \pm 9.725$ & & $35.07 \pm 9.786$ & \\
\hline $16-20$ years & 27 & $15.37 \pm 2.950$ & & $38.04 \pm 5.841$ & & $38.11 \pm 4.766$ & \\
\hline More than 20 years & 12 & $16.58 \pm 2.575$ & & $37.75 \pm 7.653$ & & $36.25 \pm 6.107$ & \\
\hline \multicolumn{3}{|c|}{$\begin{array}{l}\text { Retrieval Number:E11480585C19/2019@BEIESP } \\
\text { DOI: 10.35940/ijeat.E1148.0585C19 }\end{array}$} & \multicolumn{3}{|c|}{$\begin{array}{l}\text { Published By: } \\
\text { Blue Eyes Intelligence Engineering } \\
\& \text { Sciences Publication }\end{array}$} & & \\
\hline
\end{tabular}




\begin{tabular}{|l|r|l|l|l|l|l|l|}
\hline Not stated & 1 & & & & & & \\
\hline Total & 173 & & & & & & \\
\hline
\end{tabular}

\section{ACKNOWLEDGMENT}

This research was funded by the Incentive Grant for Research in Teaching and Learning (GIPP), Universiti Putra Malaysia (Code project: GIPP-9323697).

\section{REFERENCES}

1. Du Plessis LE. The implementation of outcomes-based education in the Eastern Cape: A management perspective at micro level. 2005.

2. Ortega RAA, Cruz RAOD. Educators' attitude towards outcomes-based educational approach in English second language learning. Am J Educ Res 2016; 4: 597-601.

3. Ministry of Higher Education. Graduates Tracer Study. 2018.

4. Department of Statistics Malaysia. Key Statistics of Labour Force in Malaysia, July 2018.

5. Balakrishnan N. Malaysian Fresh Grads Can't Get Jobs Because They Have Attitude Problems. SAYS.

6. Goldsmith A, Zahari MSM. Hospitality education in Malaysia: Filling the skill gap. Int J Contemp Hosp Manag 1994; 6: 27-31.

7. Kaliannan M, Chandran SD. Empowering students through outcome-based education (OBE). Res Educ 2012; 87: 50-63.

8. Karim AMA, Abdullah N, Rahman AMA, et al. A nationwide comparative study between private and public university students' soft skills. Asia Pacific Educ Rev 2012; 13: 541-548.

9. Weinstein J. Schools, companies, grads create false expectations. Restaur Institutions 1989; 9: 20-21.

10. [Alderson A, Martin M. Outcomes based education: Where has it come from and where is it going? Issues Educ Res 2007; 17: 161-182.

11. Chee-ming C, Shamsudin A, Suratkon A. The essence of OBE and implementation experiences in Malaysia. In: International Conference on Operations Excellence and Service Engineering. Orlando, Florida, USA, 2015.

12. Malan SPT. The 'new paradigm' of outcomes-based education in perspective. J Fam Ecol Consum Sci 2000; 28: $22-28$.

13. Akir $\mathrm{O}$, Eng $\mathrm{TH}$, Malie S. Teaching and learning enhancement through outcome-based education structure and technology e-learning support. Procedia-Social Behav Sci 2012; 62: 87-92.

14. Harden RM. Outcome-based education-the ostrich, the peacock and the beaver. Med Teach 2007; 29: 666-671.

15. Harden RM, Crosby JR, Davis MH, et al. AMEE Guide No. 14: Outcome-based education: Part 5-From competency to meta-competency: A model for the specification of learning outcomes. Med Teach 1999; 21: 546-552.

16. Morcke AM, Eika B. Medical faculty and curriculum design - 'No, no,it's like this: You give your lectures...' Med Teach 2009; 31: 642-648q.

17. Neofa Z. A case study of how primary school teachers in Papua New Guinea understand outcomes-based education. 2010.

18. Barman L, Silén C, Laksov KB. Outcome based education enacted: teachers' tensions in balancing between student learning and bureaucracy. Adv Heal Sci Educ 2014; 19: 629-643.

19. Davis MH, Amin Z, Grande JP. Case studies in outcomebased education. Med Teach 2007; 29: 717-722.
20. Grunwald H, Peterson MW. Factors that promote faculty involvement in and satisfaction with institutional and classroom student assessmente. Res High Educ 2003; 44: 173-204.

21. Muffo J. Institutional effectiveness, student learning, and outcomes assessment. In: Institutional research: Decision support in higher education. Tallahassee, FL: Association for Institutional Research, 2001.

22. Newble D, Stark P, Bax N, et al. Developing an outcome-focused core curriculum. Med Educ 2005; 39: 680-687.

23. Palomba CA, Banta TW. Assessment essentials: Planning, implementing, and improving assessment in higher education. San Francisco, CA: Jossey-Bass Publishers, 1999.

24. Ramoroka NJ. Educators' understanding of the premises underpinning outcomes-based education and its impact on their classroom assessment practices. 2006.

25. Mager RF. Preparing instructional objectives. Georgia: CEP Press, 1997.

26. Brandt R. On outcome-based education: A conversation with Bill Spady. Educ Leadersh 1992; 50: 66-70.

27. Spady WG. Outcome-based education: Critical issues and answers. Arlington, VA: American Association of School Administrators, 1994.

28. Shields HM. A medical teacher's manual for success: Five simple steps. Baltimore, MD: Johns Hopkins University Press, 2011.

29. Ministry of Education Malaysia. Executive Summary: Malaysia Education Blueprint 2015-2025 (Higher education). 2015.

30. Malaysian Qualifications Agency. Code of Practice for Program Accreditation Second Edition. 2018.

31. Boud D, Falchikov N. Redesigning assessment for learning beyond higher education. Res Dev High Educ 2005; 28: 34-41.

32. Fook CY, Sidhu GK. Authentic assessment and pedagogical strategies in higher education. J Soc Sci 2010; 6: 153-161.

33. Morton SMB, Bandara DK, Robinson EM, et al. In the 21 st Century, what is an acceptable response rate? Aust $N$ Z J Public Health 2012; 36: 106-108.

34. Habermann M, Blackhurst J, Metcalf AY. Keep your friends cose? Supply chain design and disruption risk. Decis Sci 2015; 46: 491-526.

35. Bennett L, Nair CS. A recipe for effective participation rates for web-based surveys. Assess Eval High Educ 2010; 35: 357-365.

36. McPeake J, Bateson M, O'Neill A. Electronic surveys: How to maximise success. Nurse Res 2013; 21: 24-26.

37. [Nulty DD. The adequacy of response rates to online and paper surveys: What can be done? Assess Eval High Educ 2008; 33: 301-314.

38. Fan W, Yan Z. Factors affecting response rates of the web survey: A systematic review. Comput Human Behav 2010; 26: 132-139. 
International Conference on Recents Advancements in Engineering and Technology (ICRAET-18) |15th and 16th March 2019|Siddhartha Institute of Technology \& Sciences, Telangana, India.

\section{AUTHORS PROFILE}

Siti Fatimah Mohamad obtained Ph.D. in Management from Universiti Putra Malaysia. She is a senior lecturer at the Department of Foodservice Management, Universiti Putra Malaysia. Her research interest includes human resource management and employer branding.

Ungku Fatimah Ungku Zainal Abidin obtained $\mathrm{Ph.D.}$ in Hospitality Management from Iowa State University. She is a senior lecturer at the Department of Foodservice Management, Universiti Putra Malaysia. Her research interest includes food safety management and food service management.

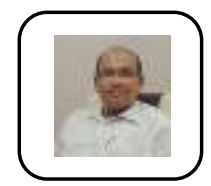

Nazamid Saari obtained Ph.D. in Food Biochemistry and Enzymology from Kagoshima University. He is a professor at the Department of Food Science, Universiti Putra Malaysia. His research interest includes food enzymology, food biochemistry/biotechnology, food chemistry/functional foods, and food proteins.

Muta Harah Zakaria obtained Ph.D. in Aquatic Biology from Universiti Putra Malaysia. She is a professor at the Department of Aquaculture, Universiti Putra Malaysia. Her research interest includes aquatic biology, marine biology and ecology

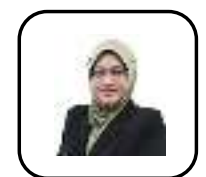

Alyani Ismail obtained Ph.D. in Electronics Engineering from University of Birmingham. She is a professor at the Department of Computer and Communication Systems Engineering, Universiti Putra Malaysia. Her research interest includes micromachining microwave devices, microwave waveguides, microwave filters, and RF MEMS

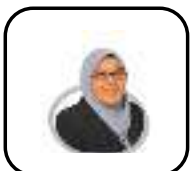

Nor Azirawani Man is a social research officer at the Division Head, Development of Teaching and Learning, Center for Academic Development, Universiti Putra Malaysia. 